\title{
HYDROPONIC PH MODIFIERS AFFECT PLANT GROWTH AND NUTRIENT CONTENT IN LEAFY GREENS
}

\author{
Hardeep SINGH*, Bruce DUNN, Mark PAYTON \\ Department of Horticulture and Landscape Architecture, \\ Oklahoma State University, Stillwater, OK 74078-6027, USA
}

Received: April 2019; Accepted: June 2019

\begin{abstract}
Use of hydroponics is increasing because of its ability to be used for year round vegetable production using an environmentally sustainable system. Management of solution $\mathrm{pH}$ is an important challenge in hydroponics systems. Our objective was to quantify the effects of various $\mathrm{pH}$ modifiers on growth and nutrient uptake of leafy greens and stability of nutrient solution's $\mathrm{pH}$. Lettuce, basil, and Swiss chard were transplanted into an Ebb and flow system, and nutrient solution $\mathrm{pH}$ was maintained using three different $\mathrm{pH}$ modifiers ( $\mathrm{pH}$ Down, lime juice, or vinegar). The nutrient solution's $\mathrm{pH}$ was maintained between 5.5 and 6.5. $\mathrm{pH}$ Down resulted in the most stable solution $\mathrm{pH}$ and required the least amount of product used when compared to lime juice and vinegar. The cost of using phosphoric acid or lime juice was greater than that of using vinegar. Vinegar reduced the yield of all crops in comparison to $\mathrm{pH}$ Down. When compared to $\mathrm{pH}$ Down, lime juice reduced the yield of basil and Swiss chard but not that of lettuce. Therefore, growers can use lime juice as an alternative to $\mathrm{pH}$ Down in lettuce production but not for basil and Swiss chard, while vinegar would not be recommended for any of the crops studied.
\end{abstract}

Keywords: soilless culture, nutrients, lettuce, basil, Swiss chard, chlorophyll meter

\section{INTRODUCTION}

By 2050 , the human population is expected to reach 8.9 billion (USAID 2004), and a major challenge for the increased population will be maintaining the supply of fresh produce to ensure nutrientrich diets. Hydroponic or soilless production could be an important solution to this problem because of its higher yields and more nutritious food when compared to soil production (Skagg 1996). Hydroponics can be defined as a technique of growing non-aquatic plants without soil in a nutrient solution with or without soilless substrate (Arancon et al. 2015). Maintaining an adequate nutrient solution and $\mathrm{pH}$ level are often cited as major obstacles to hydroponic production (Steiner 1961). Frick and Mitchell (1993) indicated that $\mathrm{pH}$ of a hydroponic nutrient solution fluctuates because of the unbalanced anion and cation exchange reaction with roots and there is no buffering capacity in hydroponics as in soil.

Plant essential nutrient availability varies with $\mathrm{pH}$. According to Resh (2004), slightly acidic $\mathrm{pH}$ is optimum for hydroponic production because iron $(\mathrm{Fe})$, manganese $(\mathrm{Mn})$, calcium $(\mathrm{Ca})$, and magnesium $(\mathrm{Mg})$ may form precipitates and become unavailable at $\mathrm{pH}$ above 7. Islam et al. (1980) reported that at higher $\mathrm{pH}$, the amount of $\mathrm{Fe}, \mathrm{Mn}, \mathrm{Mg}$, potassium $(\mathrm{K})$, and $\mathrm{Ca}$ increased in the plants, but these elements were not translocated to the shoot but instead remained stored in the roots. Bugbee (2003) also reported that availability of $\mathrm{K}$ and phosphorus (P) is slightly reduced in a nutrient solution with high pH. Dyśko et al. (2008) also reported that the increase in nutrient solution's $\mathrm{pH}$ led to the decrease in available $\mathrm{P}$ for hydroponic production of tomato (Solanum lycopersicum L.). Chen et al. (2016) also reported a difference in nutrient uptake of lettuce 
with solution $\mathrm{pH}$ when using wood vinegar. Hochmuth (2001) recommended a nutrient solution's $\mathrm{pH}$ of 5.5-6.5 for greenhouse hydroponic production, whereas Resh (2004) recommended a pH of 5.8-6.4. Ahn and Ikeda (2004) also reported a $\mathrm{pH}$ of 5-7 as optimum for hydroponic cultivation of Chinese chive (Allium tuberosum Rottler ex Spreng.). Whipker et al. (1996) various studies examining optimum $\mathrm{pH}$ for hydroponic lettuce (Lactuca sativa L.) production reported a decrease in leaf area, shoot dry weight, leaf length and width, and stomatal conductance because of the exposure to a suboptimal solution $\mathrm{pH}$.

There are various chemicals that can be used to lower the $\mathrm{pH}$ of a nutrient solution in hydroponics. Burleigh et al. (2008) recommended the use of citric acid (lime juice), acetic acid (vinegar), nitric acid, phosphoric acid, and sulfuric acid for lowering $\mathrm{pH}$ of the water used for plant cultivation. Chen et al. (2016) also reported that pyroligneous acid (wood vinegar) can be used for hydroponic cultivation of lettuce at a rate of $0.25 \mathrm{ml} \cdot \mathrm{dm}^{-3}$ while evaluating different strengths of wood vinegar as a pH buffer. Frick and Mitchell (1993) compared the use of 2-(N-morpholino)ethanesulfonic acid (MES) buffer and Amberlite DP-1 (cation-exchange resin beads, $16-50$ wet mesh, $8.1 \mathrm{mEq} \cdot \mathrm{g}^{-1}$ ) for stabilizing the $\mathrm{pH}$ of nutrient solution for the production of mustard (Brassica juncea L.). The concentration of chemicals used for $\mathrm{pH}$ stabilization can also affect plant growth. Stahl et al. (1999) used different concentrations of MES for hydroponic culture and concluded that plant growth was affected with increasing concentrations. Stabilizing the $\mathrm{pH}$ of a nutrient solution is necessary for optimum crop productivity in hydroponics (Frick \& Mitchell 1993). Identifying a more economical and readily available product for reducing the $\mathrm{pH}$ of the solution without reducing the crop yield would be beneficial to growers (Kirimura \& Inden 2005). Therefore, the objective of this study was to evaluate the use of lime juice, vinegar, and a commercial $\mathrm{pH}$ buffer (pH Down) as $\mathrm{pH}$ modifiers in hydroponics and their effect on plant growth, chlorophyll content, and nutrient uptake of leafy greens.

\section{MATERIALS AND METHODS}

\section{Plant material and growth conditions}

The research was conducted at the Department of Horticulture and Landscape Architecture Research Greenhouses in Stillwater, OK, under natural photoperiods. Temperature was set at $21^{\circ} \mathrm{C} / 18{ }^{\circ} \mathrm{C}$ day/night with a photosynthetic photon flux density (PPFD) range of $600-1,200 \mu \mathrm{mol} \cdot \mathrm{m}^{-2} \cdot \mathrm{s}^{-1}$ at $1,200 \mathrm{HR}$. Seeds of red lettuce 'Oscarde', basil (Ocimum basilicum L. 'Citrus') and Swiss chard (Beta vulgaris L. 'Magenta Sunset'), were obtained from Johnny's Selected Seeds (Winslow, ME). Seeds were sown in $1.5 \mathrm{~cm}^{3}$ rockwool starter cubes (Gordan, Milton, $\mathrm{ON}$ ) on 2 February 2017. A styrofoam sheet was used to support the plants, and $5 \mathrm{~cm}$ diameter slots were drilled into the sheet with a spacing of $28 \mathrm{~cm} \times 28 \mathrm{~cm}$. Upon obtaining two true leaves (March 6, 2017), plants were transplanted into $5-\mathrm{cm}$ net pots on Ebb and flow tables (Gro Master, Maple Park (Virgil), IL). Plants were randomly assigned to 1 of 30 net pots on each of 3 tables resulting in 10 replicates of each crop species per table. Each table was randomly assigned one of the three $\mathrm{pH}$ modifier treatments: white vinegar (5\% acidity; Wal-Mart Stores Inc., Bentonville, AR), lime juice $\left(1.06 \mathrm{~g} \cdot \mathrm{oz}^{-1}\right.$ citric acid; Dr. Pepper Snapple Group, Plano, TX), and pH Down (General Hydroponics, Santa Rosa, CA). The lime juice was diluted to reach a $\mathrm{pH}$ of 2.5 similar to the other two products. The plants were harvested 30 days after transplanting. The entire experiment was repeated three times with planting also occurring on 20 March and 25 April 2017 and transplanting occurring on 25 April and 3 June 2017 for the second and third runs, respectively.

\section{Fertilizers and EC}

The nutrient solution was designed using a commercially available soluble fertilizer (Peters 5-5.2-21.6, J.R. Peters Allentown, PA), calcium nitrate (American Plant Products), and local tap water $(\mathrm{EC}=$ $0.5 \mathrm{mS} \cdot \mathrm{cm}^{-2}, \mathrm{pH}=7.8$ ). Initial solutions were produced using manufacturer recommendations of $147.41 \mathrm{~g} \cdot \mathrm{dm}^{-3}$ of Peters and $97.52 \mathrm{~g} \cdot \mathrm{dm}^{-3}$ of calcium nitrate. The hydroponics system had a $141.4 \mathrm{dm}^{3}$ of tank capacity and was circulated using a $189 \mathrm{dm}^{3} \cdot \mathrm{min}^{-1}$ pump (Wayne, Harrison, $\mathrm{OH}$ ). 
The EC and $\mathrm{pH}$ of the solution were measured every other day using a $\mathrm{pH} / \mathrm{EC}$ meter (Hanna Instruments, Woonsocket, RI). The EC of the nutrient solution was checked every other day to maintain the EC at $1.5-2.5 \mathrm{ds} \cdot \mathrm{m}^{-1}$ and the $\mathrm{pH}$ at $5.5-6.5$ by adding fertilizer and $\mathrm{pH}$ solution.

\section{Data Collection}

At the end of the study, data were collected on fresh shoot weight and dried shoot and root weight (plants cut at substrate level and dried for 2 days at $56.6^{\circ} \mathrm{C}$ ). Three leaves (top, middle, and bottom) from each plant were scanned using a SPAD-502 chlorophyll meter (SPAD-502, Konica Minolta, Japan) at the time of harvest. Dried shoot samples were analyzed for nitrogen content by the Soil, Water and Forage Analytical Laboratory (SWFAL) at Oklahoma State University, using a LECO TruSpec Carbon and Nitrogen Analyzer (LECO Corporation, St. Joseph, MI).

\section{Statistics}

The experimental design was a split-plot design with 3 replications of 10 individual replicates per species per run; Factors were $\mathrm{pH}$-lowering products (three levels) and species (three levels). Data were subjected to an analysis of variance (ANOVA) using PROC MIXED with the LSMEANS statement and DIFF option within the SAS/STAT software, version 9.4 (SAS Institute, Cary, NC). Tests of significance are reported at the $0.05,0.001$, and 0.0001 levels. Treatment means were separated using Fisher's protected least significance difference (LSD) method. Statistical analyses were conducted for each crop separately.

\section{RESULTS}

\section{Effect of different $\mathrm{pH}$ products on nutrient solu- tion's pH}

Nutrient solution's $\mathrm{pH}$ increased on a near-liner trend for all three modifiers; however, $\mathrm{pH}$ Down appeared to plateau around a $\mathrm{pH}$ of 6.7 starting around 25 days (Fig. 1). The $\mathrm{pH}$ was in the required range (5.5-6.5) throughout the growth cycle for treatments using phosphoric acid, whereas for treatments using lime juice and vinegar, the $\mathrm{pH}$ reached 7.5 at harvest (Fig. 1). Across the three experimental runs, the total amount of lime, vinegar, and $\mathrm{pH}$ Down used per run was $6,000 \mathrm{ml} ; 8,000 \mathrm{ml}$; and $600 \mathrm{ml}$, respectively.

Effect of different pH products on growth and chlorophyll content of lettuce, basil, and Swiss chard

The fresh weight and dry shoot weight of lettuce were significantly lower with vinegar than with the other treatments, while there was no significant difference between lime juice and phosphoric acid (Table 1). There was no significant difference in dry weight of lettuce roots among the treatment groups. The SPAD values were lowest for lime juice, and there was no significant difference between vinegar and phosphoric acid (Table 1).

The fresh and dry shoot weight of basil was significantly greater for phosphoric acid than other $\mathrm{pH}$ modifier treatments. The dry root weight of basil was significantly lower for vinegar than other treatments, whereas no significant difference was observed between lime juice and phosphoric acid. The SPAD values were significantly greater for phosphoric acid than for lime juice or vinegar (Table 2).

The fresh and dry shoot weight of Swiss chard was greatest for plants grown with phosphoric acid (Table 3). The dry weight of Swiss chard roots was lowest using vinegar, whereas no significant difference was observed between among lime juice and phosphoric acid. No significant difference was observed for SPAD values among all three treatments of Swiss chard (Table 3).

Effect of different $\mathrm{pH}$ products on nutrient content of lettuce, basil, and Swiss chard

Nitrogen $(\mathrm{N})$ and $\mathrm{K}$ contents for lettuce and basil were significantly lower for the lime and vinegar treatments when compared to the phosphoric acid treatment (Table 4). This corresponded to lower SPAD values in both lime- and vinegar-treated nutrient solution when compared to that treated with phosphoric acid. There was no significant difference in the $\mathrm{P}$ content among the different treatments for either lettuce or basil; also, there was no significant difference in $\mathrm{N}$ or $\mathrm{K}$ content among treatments for Swiss chard (Table 4). Plant micronutrient content was not affected by $\mathrm{pH}$ buffer treatment (data not presented). 




Fig. 1. Nutrient solution's pH before adjustment during the production of lettuce 'Oscarde', basil 'Citrus', and Swiss chard 'Magenta Sunset'

Table 1. Effects of different $\mathrm{pH}$ modifiers on 'Oscarde' lettuce growth and chlorophyll content after 30 days in Ebb and flow system $(\mathrm{n}=30)$

\begin{tabular}{lcccc}
\hline \multicolumn{1}{c}{ Treatment } & Shoot FW $(\mathrm{g})^{* * *^{\mathrm{Z}}}$ & Shoot DW $(\mathrm{g})^{* *}$ & ${\text { Root DW }(\mathrm{g})^{\mathrm{NS}}}^{\text {SPAD }^{*}}$ \\
\hline pH Down & $235.9 \mathrm{a}^{\mathrm{y}}$ & $7.7 \mathrm{a}$ & $0.7 \mathrm{a}$ & $22.2 \mathrm{a}$ \\
Lime juice & $210.8 \mathrm{a}$ & $7.8 \mathrm{a}$ & $0.8 \mathrm{a}$ & $20.5 \mathrm{~b}$ \\
Vinegar & $116.7 \mathrm{~b}$ & $5.7 \mathrm{~b}$ & $0.7 \mathrm{a}$ & $22.6 \mathrm{a}$ \\
\hline
\end{tabular}

$\mathrm{z}$ indicates significant at or non-significant (NS) at $* \mathrm{p} \leq 0.05, * * \mathrm{p} \leq 0.001$, or $* * * \mathrm{p} \leq 0.0001$

y LS means within a column followed by same lowercase letter are not significantly different by pairwise comparison in mixed model $(\mathrm{p} \leq 0.05)$

Table 2. Effects of different $\mathrm{pH}$ modifiers on 'Citrus' basil growth and chlorophyll content after 30 days in Ebb and flow system $(\mathrm{n}=30)$

\begin{tabular}{lcccc}
\hline \multicolumn{1}{c}{ Treatment } & Shoot FW $(\mathrm{g})^{* * * *}$ & Shoot DW $(\mathrm{g})^{* * * *}$ & Root DW $(\mathrm{g})^{*}$ & SPAD $^{*}$ \\
\hline pH Down & $293.0 \mathrm{a}^{\mathrm{y}}$ & $24.6 \mathrm{a}$ & $4.2 \mathrm{a}$ & $26.0 \mathrm{a}$ \\
Lime juice & $213.6 \mathrm{~b}$ & $19.1 \mathrm{~b}$ & $4.3 \mathrm{a}$ & $24.5 \mathrm{~b}$ \\
Vinegar & $151.8 \mathrm{c}$ & $13.4 \mathrm{c}$ & $3.3 \mathrm{~b}$ & $23.6 \mathrm{~b}$ \\
\hline
\end{tabular}

Note: see Table 1

Table 3. Effects of different $\mathrm{pH}$ modifiers on 'Magenta Sunset' Swiss chard growth and chlorophyll content after 30 days in Ebb and flow system $(\mathrm{n}=30)$

\begin{tabular}{lcccc}
\hline \multicolumn{1}{c}{ Treatment } & Shoot FW $(\mathrm{g})^{* * Z^{2}}$ & Shoot DW $(\mathrm{g})^{* * *}$ & Root DW $(\mathrm{g})^{*}$ & SPAD $^{\mathrm{NS}}$ \\
\hline pH Down & $187.7 \mathrm{a}^{\mathrm{y}}$ & $10.9 \mathrm{a}$ & $1.4 \mathrm{a}$ & $42.6 \mathrm{a}$ \\
Lime juice & $118.8 \mathrm{~b}$ & $7.6 \mathrm{~b}$ & $1.0 \mathrm{a}$ & $42.1 \mathrm{a}$ \\
Vinegar & $50.1 \mathrm{c}$ & $4.3 \mathrm{c}$ & $0.3 \mathrm{~b}$ & $42.0 \mathrm{a}$ \\
\hline
\end{tabular}

Note: see Table 1

Table 4. Effects of different $\mathrm{pH}$ modifiers on macronutrients element of lettuce 'Oscarde', basil 'Citrus', and Swiss chard 'Magenta Sunset' $(\mathrm{n}=3)$

\begin{tabular}{|c|c|c|c|c|c|c|c|c|c|}
\hline \multirow{2}{*}{ Treatment } & \multicolumn{3}{|c|}{ Nitrogen $(\%)$} & \multicolumn{3}{|c|}{ Phosphorus (\%) } & \multicolumn{3}{|c|}{ Potassium (\%) } \\
\hline & lettuce $^{* * z}$ & basil ${ }^{\text {*** }}$ & Swiss chard $^{\mathrm{NS}}$ & lettuce $^{\mathrm{NS}}$ & basil ${ }^{\mathrm{NS}}$ & Swiss chard $^{\mathrm{NS}}$ & lettuce $^{*}$ & basil $^{*}$ & Swiss chard ${ }^{\mathrm{NS}}$ \\
\hline pH Down & $4.8 \mathrm{a}^{\mathrm{y}}$ & $5.2 \mathrm{a}$ & $4.3 \mathrm{a}$ & $0.7 \mathrm{a}$ & $1.3 \mathrm{a}$ & $0.4 \mathrm{a}$ & $6.2 \mathrm{a}$ & $0.8 \mathrm{a}$ & $2.1 \mathrm{a}$ \\
\hline Lime juice & $4.4 \mathrm{~b}$ & $4.2 \mathrm{~b}$ & $4.5 \mathrm{a}$ & $0.7 \mathrm{a}$ & $1.3 \mathrm{a}$ & $0.4 \mathrm{a}$ & $6.0 \mathrm{~b}$ & $0.6 \mathrm{~b}$ & $2.2 \mathrm{a}$ \\
\hline Vinegar & $4.8 \mathrm{a}$ & $4.2 \mathrm{a}$ & $4.1 \mathrm{a}$ & $0.7 \mathrm{a}$ & $1.3 \mathrm{a}$ & $0.5 \mathrm{a}$ & $6.1 \mathrm{~b}$ & $0.7 \mathrm{~b}$ & $2.1 \mathrm{a}$ \\
\hline
\end{tabular}

Note: see Table 1 


\section{DISCUSSION}

The authors hypothesize that the initial delay in $\mathrm{pH}$ increase may be because the nutrient uptake was less during the first week because of the small size of the plant as well as a smaller leaf surface area for transpiration of water. During the second week, as the plants grew, more nutrients and water were taken up. This may have led to an uneven uptake of anions and cations, which is one of the causes of $\mathrm{pH}$ change in a nutrient solution (Frick \& Mitchell 1993). Chen et al. (2016) also reported that $\mathrm{pH}$ was more stable during the first week of the growth cycle but increased thereafter. In contrast to the results of the present study, Lee and Lee (2006) reported that because of balanced nutrient uptake during the growth cycle, the nutrient solution $\mathrm{pH}$ remained stable during hydroponic production of leafy greens. Because our water $\mathrm{pH}$ is alkaline $(\mathrm{pH} 7.8)$, adding water to replenish levels in the tank increased the pH. According to Sinclair and Eny (1946), juices such as lemon juice consisting of citric acid can also be used as an organic buffer to resist changes in the $\mathrm{pH}$ when hydrogen or hydroxyl ions are added. In this study, citric acid alone was only effective for a day then the $\mathrm{pH}$ increased steadily, whereas with pH Down, which also contains citric acid, ammonium dihydrogenorthophosphate, and phosphoric acid, the $\mathrm{pH}$ level did not fluctuate as rapidly and stabilized at the end.

The color of leafy green vegetables is an important attribute affecting consumer preference (Ali et al. 2009). Chlorophyll meters can be used to estimate the greenness of leafy green vegetables as Colonna et al. (2016) used a SPAD meter to estimate nitrogen $(\mathrm{N})$ content of leaves as a nondestructive method. Singh et al. (2019) reported that SPAD values ranged from 17 to 28 for different cultivars of lettuce, which corresponded with our values, but found 'Oscarde' to have a greater SPAD value. The lower SPAD values for basil treated with lime juice and vinegar corresponded to visual observations of chlorosis and lower tissue $\mathrm{N}$ content. Chen et al. (2016) found that use of wood vinegar at high concentrations $\left(1 \mathrm{ml} \cdot \mathrm{dm}^{-3}\right)$ in hydroponic lettuce production may lead to decreased nitrate- $\mathrm{N}$ uptake, photosynthesis rate, and chlorophyll content.
In contrast, the lower SPAD values for lettuce plants treated with lemon juice did not show evidence of chlorosis, which may be the result of using a red leafed cultivar.

Generally, inorganic acids such as nitric acid, sulfuric acid, and phosphoric acid are used for reducing and stabilizing the nutrient solution's $\mathrm{pH}$ in hydroponic production. This may also affect the nutrient composition of the solution as nitric acid may contribute to the nitrate form of $\mathrm{N}$ and sulfuric acid may contribute to sulfate ions and it would be hard for a normal grower to calculate the amount of nutrients added every time the $\mathrm{pH}$ buffer is added (Chen et al. 2016). Lei et al. (2004) reported hydroponic vegetables to be higher in nitrate concentration as compared to soil grown vegetables, which is harmful for human consumption. Greater leaf nitrogen and potassium values were observed for 'Oscarde' and 'Citrus', which is not unexpected for $\mathrm{pH}$ Down containing additional ammonium and phosphates. The additional nitrogen was unexpected for vinegar, which is derived from ethanol to produce acetic acid. Kirimura and Inden (2005) reported that using safe, natural, and less-expensive acidic material is more beneficial for hydroponic production as compared to inorganic acids. This contradicts what we found, as vinegar and lime juice reduced the plant growth for 'Citrus' and 'Magenta Sunset' and reduced the plant quality in 'Oscarde' compared to $\mathrm{pH}$ Down. The effect of lime juice and vinegar on basil and Swiss chard may be due to the use of too high of concentrations to maintain a desirable $\mathrm{pH}$ level.

\section{CONCLUSION}

From the results of the present experiment, lime juice or $\mathrm{pH}$ Down can be used as a $\mathrm{pH}$ modifier for hydroponic production of 'Oscarde' as chlorosis is not prominent in red cultivars. For hydroponic production of basil, only pH Down should be used, because the use of lime juice and vinegar leads to lower SPAD values (chlorosis), less $\mathrm{N}$ uptake, and reduced growth. For Swiss chard, pH Down would be recommended for greater growth. For all three species, $\mathrm{pH}$ Down had lower production costs of $\$ 2.60$ compared to $\$ 8$ and $\$ 26.40$ for vinegar and lime juice, respectively, and had a greater affect at maintaining the $\mathrm{pH}$. 
Future research should investigate the use of different organic acids, concentrations, combination with other buffering compound, or different cultivars of basil, Swiss chard, and lettuce.

\section{REFERENCES}

Ahn D.-H., Ikeda H. 2004. Effects of $\mathrm{pH}$ and concentration of nutrient solution on growth of hydroponically cultured Chinese chive (Allium tuberosum Rottler). Horticultural Research (Japan) 3: 191-194. DOI: 10.2503/hrj.3.191. [in Japanese with English abstract]

Ali M.B., Khandaker L., Oba S. 2009. Comparative study on functional components, antioxidant activity and color parameters of selected colored leafy vegetables as affected by photoperiods. Journal of Food, Agriculture and Environment 7: 392-398.

Arancon N.Q., Schaffer N., Converse C.E. 2015. Effects of coconut husk and sphagnum moss-based media on growth and yield of romaine and buttercrunch lettuce (Lactuca sativa) in a non-circulating hydroponics system. Journal of Plant Nutrition 38: 1218 1230. DOI: $10.1080 / 01904167.2014 .983117$.

Bugbee B. 2003. Nutrient management in recirculating hydroponic culture. Acta Horticulture 648: 99-112. DOI: 10.17660/actahortic.2004.648.12.

Burleigh M., Roberts E., Wagner D.R. 2008. Acidic solutions adjusting water's $\mathrm{pH}$ improves plant growth. Cactus and Succulent Journal 80: 245-250. DOI: 10.2985/0007-9367(2008)80[245:asawpi]2.0.co;2.

Chen J., Wu J.H., Si H.P., Lin K.Y. 2016. Effects of adding wood vinegar to nutrient solution on the growth, photosynthesis, and absorption of mineral elements of hydroponic lettuce. Journal of Plant Nutrition 39: 456-462. DOI: 10.1080/01904167.2014.992539.

Colonna E., Rouphael Y., Barbieri G., De Pascale S. 2016. Nutritional quality of ten leafy vegetables harvested at two light intensities. Food Chemistry 199: 702-710. DOI: 10.1016/j.foodchem.2015.12.068.

Dyśko J., Kaniszewski S., Kowalczyk W. 2008. The effect of nutrient solution $\mathrm{pH}$ on phosphorus availability in soilless culture of tomato. Journal of Elementology 13: 189-198.

Frick J., Mitchell C.A. 1993. Stabilization of pH in solidmatrix hydroponic systems. HortScience 28: 981984. DOI: 10.21273/hortsci.28.10.981.

Hochmuth G.J. 2001. Fertilizer management for greenhouse vegetables. Florida greenhouse vegetable production handbook, vol. 3. HS787. Florida Cooperative Extension Service, University of Florida. http://edis.ifas.ufl.edu/cv265 [accessed August 5, 2018]

Islam A.K.M.S., Edwards D.G., Asher C.J. 1980. pH optima for crop growth. Results of a flowing solution culture experiment with six species. Plant and Soil 54: 339-357. DOI: 10.1007/bf02181830.

Kirimura M., Inden H. 2005. Effects of set point of $\mathrm{NH}_{4}$ $\mathrm{N}$ concentration on $\mathrm{pH}$ fluctuation in ion concentration controlled hydroponics in cucumber. Journal of Science and High Technology in Agriculture (Japan) 17: 199-204. DOI: 10.2525/shita.17.199. [in Japanese with English abstract]

Lei J.L., Chen J., Dai D.L., Chen L., Zhou S., Shou W., et al. 2004. Study on the hydroponics technique of leafy vegetables with low-nitrate content. Acta Agriculturae Zhejiangensis 16: 102-104.

Lee Y.C., Lee W.S. 2006. Effect of culture solution formula and the reagent level to the growth in lettuce and Pak-Choi. Horticulture NCHU 31: 31-40.

Resh H.M. 2004. Hydroponic Food Production, $6^{\text {th }}$ ed. Newconcept Press, Mahwah, USA, 567 p.

SAS 2013. Base SAS ${ }^{\circledR} 9.4$ Procedures Guide: Statistical Procedures, $2^{\text {nd }}$ ed. SAS Institute, USA.

Sinclair W.B., Eny D.M. 1946. Stability of the buffer system of lemon juice. Plant Physiology 21: 522-532. DOI: 10.1104/pp.21.4.522.

Singh H., Dunn B., Payton M. Brandenberger L. 2019. Fertilizer and cultivar selection of lettuce, basil, and Swiss chard for hydroponic production. HortTechnology 29: 50-56. DOI: 10.21273/horttech04178-18.

Skagg K. 1996. The urban gardener. American Horticulturist 75: 9-10.

Steiner A.A. 1961. A universal method for preparing nutrient solutions of a certain desired composition. Plant and Soil 15: 134-154. DOI: 10.1007/bf01347224.

Stahl R., Grossl P., Bugbee B. 1999. Effect of 2(N-morpholino)ethane)sulfonic acid (MES) on the growth and tissue composition of cucumber. Journal of Plant Nutrition 22: 315-330. DOI: 10.1080/01904169909365629.

USAID 2004. 50 Years of Global Health. Saving Lives and Building Futures. https://www.usaid.gov/sites/default/files/documents/1864/USAID_50-Years-of-

Global-Health.pdf [Accessed 5 August, 2018]

Whipker B.E., Bailey D.A., Nelson P.V., Fonteno W.C., Hammer P.A. 1996. A novel approach to calculate acid additions for alkalinity control in greenhouse irrigation water. Communications in Soil Science and Plant Analysis 27: 959-976. DOI: 10.1080/00103629609369610. 